\title{
The grouping together of the nine official African languages for academic purposes: an instance of alien rule
}

\author{
Paul H. Nkuna \\ Department of African Languages; University of South Africa
}

Email address:

nkunaph@unisa.ac.za (P. H. Nkuna)

To cite this article:

Paul H. Nkuna. The Grouping Together of the Nine Official African Languages for Academic Purposes: an Instance of Alien Rule. Education Journal. Vol. 2, No. 1, 2013, pp. 13-15. doi: 10.11648/j.edu.20130201.13

\begin{abstract}
While it has become established practice, the grouping together of the nine official African languages for academic purposes neglects the individual teaching and learning, use and status of these languages in the higher education system in South Africa. Drawing principally on Dubrow and Friedman's argument, I argue that the grouping together for academic purposes of the nine official African languages rests on academic receivership of the 'African languages' domain, enhanced by Bantu philologists. Now redefined, 'African languages' as an entity has become a force influencing the teaching and learning of and research relating to the nine official African languages - isiNdebele, isiXhosa, isiZulu, Sepedi, Sesotho, Setswana, siSwati, Tshivenda and Xitsonga. The discussion focuses on the status of the nine official African languages at South African universities and their grouping under the umbrella of 'African languages'.
\end{abstract}

Keywords: Grouping, African Languages, Alien Rule, Nine Official Lsnguages, Academic Receivership, Discourse

\section{Introduction}

The grouping together of the indigenous languages for academic purposes in South Africa is not new. As Couzens in Cross $(1986,189)$ reports, "in the universities, departments of Bantu Studies were formed. In 1918, the University of Cape Town appointed a Professor of Bantu Philology." This was followed by the "formation in 1921 of the school of African life and languages at the University of Cape Town" (Lalu, 2011,3). Werner $(1929,155)$ further reports the presence "at the University of the Witwatersrand (Johannesburg) of a Society of Bantu Studies...Zulu and Sutu are most efficiently taught."

In this paper, I explore what makes the grouping together of the nine official African languages for academic purposes alien, as it in fact contributes to diminishing the use and status of these languages. I offer a rational and expressive defence of what the status of these languages in the country's universities should be. The study is divided into three parts, a discussion of academic receivership; a discussion of the 'African languages' discourse; and a discussion of the academic receivership of 'African languages'.

\section{On Academic Receivership}

\subsection{What is Academic Receivership?}

Drawing principally on examples provided by Dubrow and Friedman, in this section of the study I argue that 'African languages' discourse has its roots in academic receivership. In the words of Dubrow and Friedman $(2005,3)$.

Academic receivership - a relatively rare event in which a departmental chair is imposed from the outside by a dean or provost when the department is judged unable to govern itself effectively - is an instance of alien rule within the academy. In one of the few articles on the subject, Charlotte Allen wrote, "Receivership is a shameful secret, a dark blot on academic reputation and institutional self-image." Strong words indeed to describe instances in which an anthropology department is chaired by an historian and a literature department is chaired by a linguist.

\subsection{Characteristics of Departmental Receivership}

Dubrow and Friedman (2005) identify four features of departmental receivership:

(1) Departments vulnerable to receivership are marked by contested disciplinary identities or transcend customary divisional structures. The boundaries of the departmental identity are set by neither internal nor external norms. 
(2) Departments at risk of receivership have become misaligned with university priorities. Almost any change in university-level strategic priorities, whether in research or education, can unleash confusion or backlash at departmental level.

(3) Departments with long histories of excellence, when faced with new disciplinary and/or institutional requirements, seem to have difficulty in responding.

(4) Departments become isolated, either from other units in the same university, or from their own discipline. Isolation creates insularity; insularity separates units from the sorts of evolutionary changes which are typically absorbed in a more gradual fashion by better connected departments.

\section{On The 'African Languages' Dis- course}

\subsection{The Field of 'African Languages' as a Result of the Failure of Bantu Philology}

The vision of African languages as a field of comparative study arose from scientific interest in African languages sparked by philologists. Tucker $(1948,493)$ states that African languages as a field of comparative study "was almost a German monopoly". Errington $(2001,19)$ affirms that around the world, from the sixteenth to the early twentieth century, "Europeans wrote about alien languages that they encountered in pursuit of their diverse colonial interest." This provided the foundation for Bantu philology. Tucker $(1957,541)$ argues that "philological studies in Africa are inevitably bound up with the vexed question of the classification of its languages". Table 1 is a partial summary of the historical classification of the indigenous languages (which include the present-day nine official African languages) in South Africa.

Table 1. Summary of the historical classification of the African languages in South Africa.

\begin{tabular}{lll}
\hline Year & Name & Researcher \\
\hline Before 1826 & Kaffrarian Family & James Coutes Prichard \\
1826 & The South African Languages & Adrien Balbi \\
1847 & Alliteral Class & John W. Appleyard \\
1848 & The Kaffir Class & John Clarke \\
1850 & The Nilotic languages & Johann Ludwig Krapf \\
1852 & Ba-languages & Heinrich Barth \\
1862 & Bantu languages & Wilhem I. H. Bleek \\
\hline
\end{tabular}

Source: Adapted from (Doke, 1984).

The term 'Bantu languages', is derived from the work of Dr W.H.I. Bleek, whom, Doke $(1984,63)$ reports that this "earned for him the title of 'the Father of Bantu Philology,' and it was he who first used the term Bantu...to designate these languages." However, Bantu philology failed (see
Table 2 below).

Table 2. Summary of the reasons for the failure of Bantu philology.

\begin{tabular}{|c|c|c|}
\hline Feature & Source & Description \\
\hline It was ridiculed & $\begin{array}{l}\text { Brincker } \\
\text { and Huber (1904) }\end{array}$ & $\begin{array}{l}\text { Work of Bantu language family is } \\
\text { held in small esteem. It is } \\
\text { unremunerative, and thought } \\
\text { by many to be unnecessary. }\end{array}$ \\
\hline It was ignored & Meinhof (1928) & $\begin{array}{l}\text { Bantu languages, Meinhof (1928: } \\
\text { 39) also confirms "were much } \\
\text { neglected by comparative philology, } \\
\text { which gave its attention to the in- } \\
\text { vestigation of inflecting languages, } \\
\text { and first of all to Indo-European } \\
\text { ones." }\end{array}$ \\
\hline $\begin{array}{l}\text { It was puzzled } \\
\text { and misplaced }\end{array}$ & Turker (1948) & $\begin{array}{l}\text { Carl Meinhof pulled the study } \\
\text { of Bantu languages out of the } \\
\text { slough of wild speculation in } \\
\text { which it was floundering }\end{array}$ \\
\hline $\begin{array}{l}\text { It had a } \\
\text { diminished status }\end{array}$ & Ziolkowski (1990) & $\begin{array}{l}\text { Sometimes philology is belittled } \\
\text { as being a set of basic tools or } \\
\text { data rather than as an approach } \\
\text { valid in its own right }\end{array}$ \\
\hline
\end{tabular}

\subsection{The Rise of the Study of 'African Languages'}

In place of Bantu Philology has arisen a study then undreamt of -, Crabtree $(1913,177)$ says, the study of the whole African language problem upon a systematic, scientific basis. Prof. Meinhof has been the pioneer in this movement, and his Bantu studies ought to be a household word for every African student.

Turker $(1948,493)$ likewise credits Carl Meinhof with "[pulling] the study of Bantu languages out of the slough of wild speculation in which it was floundering". This discourse neglects the individual teaching and teaching, use and status of the nine official African languages in the higher education system in South Africa. This section examines some implications of that neglect, especially in light of the original notion of African languages as the subject of comparative study, 'African languages' as being subject to academic receivership, and attendant constitutional requirements. Meinhof (1926) provides a vision of African languages as the subject of comparative study and outlines four features governing comparative study in the African languages class,

(1) Comparative work must take the form of thorough phonetic, grammatical and lexicographical examination of every individual language.

(2) Comparative research will facilitate the study of each language individually.

(3) Comparative research must shed some light on historical connections, and provide an insight into the relations between the various tribes.

(4) The understanding achieved is not only important from the point of view of purely abstract science, but is necessary for everyone who has to do with Africa and the 
Africans, be this a teacher, official, Bible translator or missionary.

\section{On Academic Receivership of 'Afri- can Languages'}

\subsection{Academic Core Group}

At the core of any organisation or institution, Kleiner $(2003,86)$ observes, there is a group of people who seem to call the shots. To be more precise, in Kleiner's words, "all the shots seem to be called for their benefit". In the context of this study, this group of people constitute the academic core group. The present majority of academics working in the area of the nine official African languages, the academic core group, claim to be disciples of Professor Carl Meinhof, but in fact have only a sketchy understanding of Meinhof's model of the comparative study of African languages (especially, the concept 'individual language').

\section{2. 'African Languages' Discourse Diminishes the Status of the Individual Nine Official African Languages}

Today, the academic core group exerts an influence on South African universities to adopt Meinhof's concept and treat the nine languages under discussion collectively as 'African languages'. Of the 23 universities in South Africa, 15 were considered for the purposes of this study. Of these, only $3(20 \%)$ accorded the individual languages departmental status, and the remaining $12(80 \%)$ treated the languages collectively, and had departments of 'African languages' - a discourse that neglects the teaching and learning, use and official status of these languages.

In light of section 6(2) of the Constitution (Act 108 of 1996), which recognises the equal use and status of our indigenous languages, African languages departments appear alien. The combination of African languages into a single academic unit is unethical and politically naïve, and fails to uphold the constitutional mandate of

(1) preventing the persistence of colonial work that led to the historically diminished use and status of the indigenous languages of our people and promoting university support of the state in adopting practical and positive measures to elevate the status and advance the use of the nine official African languages;

(2) granting all official languages parity of esteem and equal treatment; and

(3) affording everyone the right to receive education in the official language or languages of their choice in public educational institutions where that is reasonably practicable. In order to ensure the effective access to, and implementation of, this right, the state must consider all reasonable educational alternatives, including single-medium institutions, taking into account (a) equity; (b) practicability; and (c) the need to redress the results of past racially discriminatory laws and practices.

\section{Conclusion}

The grouping together for academic purposes of the nine official African languages is an alien rule that undermines the constitutional mandate in respect of these languages. It also supports the practice of academic receivership - an alien rule that aids the survival of the academic core group of Bantu philology.

\section{References}

[1] Brincker, P. H. and Huber, M. (1904). Contributions towards Bantu Philology. Journal of the Royal African Society, Vol. 3, No. 11, April:300-305.

[2] Crabtree, W. A. (1913). The Systematic Study of African Languages. Journal of the Royal African Society, Vol. 12, No. 46, January: 177-189.

[3] Cross, M. (1986).Historical Review of Education in South Africa, towards an assessment. Comparative Education, Vol. 22, No. 3: 185-200.

[4] Doke, C. M. (1984). The Growth of Comparative Bantu Philology. In C.M.Doke and D.T. Cole (54-79). Contributions to the History of Bantu Linguistics. Johannesburg: Witwatersrand University Press.

[5] Dubrow, G. and Friedman,D. 2005. Academic Receivership as Alien Rule. Prepared for the Conference on Alien Rule and Its Discontents, University of Washington, 3-4 June: 1-19.

[6] Errington, J. (2001). Colonial linguistics. Annual Review of Anthropology, 30: 19-39.

[7] Kleiner, A. (2003).Are You In With The In Crowd? Harvard Business Review. July: 86-92.

[8] Lalu, P. 2011. Restless Natives, Native Questions. Mail \& Guardian, 26 August.

[9] Meinhof, C. (1926). The Problems of Comparative Philology in Africa: Part II. Journal of the Royal African Society, Vol. 26, No. 101, October: 40-46.

[10] Meinhof, C. (1928). The Problem of Comparative Philology in Africa. Journal of the Royal African Society. Vol. 26, No. 101:40-46.

[11] Tucker, A. N. (1948). Obituary, Carl Meinhof. Bulletin of the School of Oriental and African Studies, University of London, Vol. 12, No. 2: 493-496.

[12] Tucker, A. N. (1957). Philology and Africa. Bulletin of the School of Oriental and African Studies, University of London, Vol. 20, No.1/3, Studies in Honour of Sir Ralph Turner,Director of the School of Oriental and African Studies: 541-554.

[13] Werner, A. (1929). Some Bantu Linguistic Problems. Journal of the Royal African Society, Vol. 28, No. 110:,155-165.

[14] Ziolkowski, J.(1990). "What Is Philology", Introduction. Comparative Literature Studies, Vol. 27, No. 1, What Is Philology: 1-12. 